ISSN 2616-7328 (Online), ISSN 2409-904X (Print)

Kitaêznavčì doslìdžennâ, 2019, No. 1, pp. 47-53

doi: https://doi.org/10.15407/chinesest2019.01.047

UDC 94(510):322:21

\title{
INCEPTION OF RELIGION IN PEOPLE'S REPUBLIC OF CHINA: INTERPRETATION AND IMPLEMENTATION
}

\author{
Suvro Parui \\ Prof. Ph.D. \\ Professor of Chinese Language \\ Amity School of Languages, Amity University, Gurgaon \\ suvroparui@gmail.com
}

This article deals with the continuous changes in the state-led institutionalization in China and their effects on structuring China's religious field; a normative discourse on religion and religious practices under secular labels. The primary focus of the study, the structural view point has been combined with the functional view point in defining religion as the system of belief, ritual practices and the organizational relationship designed to deal with ultimate matters of human life and the vindication of dogmas against contradictory evidences from realistic experience.

Key words: the discursive network, character, basic framework, system of religious management, non-religious orthodoxies and heterodoxies

\section{Introduction}

Over the last three decades China has experienced the transition of multiple forms of religiosity, which encompassed the vast range of practices including family rites of passages, temple festivals, transitional communities ${ }^{1}$ and spiritual network etc. The policies of the CCP have been directed at meeting the two central challenges facing China in the $20^{\text {th }}$ century; economic development and modernization for the benefit of world's largest population and making China and its identity as a world leader. Mostly the literature on religious policy of states during these years is generally based on the relation of paradigm shift. In which the crux of the objective has been injected on checking the restraint and control of the religion of the state. At the same time China is also identifying the limit towards the Freedom of religion in China. Just at the last half of the Great Cultural revolution in 1976, if the overall trend has been one of a gradual loosening of restrictions on religious life, the state has continued to assert its ultimate authority over the religious sphere ${ }^{2}$. It's neitheran easy job to describe the religious policy of China in a nut shell, nor a simple process like $\mathrm{ABC}$, which need to keep few steps back in the basic structure

\footnotetext{
${ }^{1}$ Interviews and conversation used for this article are the documents of 2005, 2009 with officials of the United front and Religions affairs Bureaus at the national level as well as of Shanghai, Shaanxi.

${ }^{2}$ Leung B., 1995, Religious freedom and the Constitution in the People's Republic of China: Interpretation and Implementation, Vol. 3, No. 1.

(C) 2019 Suvro Parui; Published by the A. Yu. Krymskyi Institute of Oriental Studies, NAS of Ukraine and the Ukrainian Association of Sinologists on behalf of The Chinese Studies. This is an Open Access article distributed under the terms of the Creative Commons Attribution License (https://creativecommons.org/licenses/by-nc-nd/4.0/).
} 
and religion for clear cut analysis. For microscopic analysis of the religious dynamics we must avoid unnecessary criticism on paradigm of state-religion relationship, Western experience assumes the prior mutual autonomy of religious institution and state, and also talks about clash between these state and religion. One thing to be noted here, that the political influence of religious institution does not interfere in the religious institutions and communities ${ }^{3}$. When we talk about the religious paradigm, we should go into its origin; etymologically this is nothing other than the historical trajectory of Europe, where Nation-State broke out of the shadow of Church. But in China this historical trajectory has its different connotation; when the proscription of Buddhist Sangha took place, till the $19^{\text {th }}$ century there were no local, trans-local institutions to maintain and secure its freedom from the cob wave of Imperialism, where the social system religiously keeps on steeping without making an actual control on religious and secular. This article does not merely seek to highlight the institutionalization of religion, in the Post Mao regime and how its going to effect on the basic frame work of the religious field of China and also keeps informing us about the latest type of indigenous and global forms of religiosity, which have popped up in China mainland during the 80 s. Here the discussion centers round on the "function" of a religion in state and how it creates "Red market" of religion in China, here this particular term "Red market" is used in rhetoric sense of practices of the sanctioned religious groups. The process of institutionalization of religion has been formulated by Ji Zhe: An institution could be conceived of as the general manner of the reproduction of rules and resources. If an organization is reconfigured by the encompassing external institutional arrangement, so that its structure and its rules about the reproduction and distribution of resources tend to be identical with its institutional environment, then it can be seen as an 'institutionalized' organization ${ }^{4}$. Institutionalization of religion during the Post Mao era has not been following the truly top down approach, which was strictly followed in, therefore under the centripetal pressure of leadership and complex bureaucratic system has brought away a hybrid system of regional bureaucracy and institution. Henceforth, this typical hybrid genre has reinforced to exist as dispersed hidden network, which aims to bring changes in their constitution under different categories.

\section{The Discursive Network}

The Great Cultural Revolution has its own significance and become successful in making the strong demarcation between religion and its associations. It's a fact that, the Cultural Revolution truly ended up in the 70-s when China was about to gear up its new policy of "Reform and opening up", therefore the attention directly poured into the strategy of country making, the religious institutions and associations which were still into play called on to systematize China's resurgent religiosity, and that needed to be strengthened and further institutionalized. The shift from ideological dogmatism directly plunged into the political cooperation of religious activists; gradually each and every aspect of social-religious developments hit at

${ }^{3}$ Yoshiko Ashiwa and David L. Wank, 2009, Making Religion, Making the state in China: an Introductory Essay, The politics of Religion in Modern China, (pp. 1-21), California, C.A Stanford University Press.

${ }^{4}$ Mayfair Yang, Ji Zhe, (Ed), 2008, Secularization as Religious Restructuring: Statist Industrialization of Chinese Buddhism and its Paradox, pp. 239-240, Berkeley, California, C. A. University of California Press. 
the same point, where China poured its $100 \%$, "Reform and opening up". 'Danwei' can be termed as the bi product of the policy of "Reform and opening up"; where hybridization of the secular socialist work unit has been called as 'Danwei'. There each and every workers were nationalized and assigned not only for providing better life, they are also eligible and secured their residence, welfare facilities and etc. At the same time this particular system has its limitations also.

In the late $90-\mathrm{s}$, when the system on danwei was mostly dismantled, system of religious associations was not entirely eliminated, just freed them from other boundations, to live free or die was their own choice. Today's religious culture is nothing other than the 'modified danwei' in socialist market economy. Though this sounds very common, but in reality this scenario is too painful to the religious practitioners seeking for the pure spirituality. Etymologically institutional structures are harmonious, but conflicts are indeed.

In order to understand in better way the process of institutionalization, we must put efforts to get the idea about its boundaries and network, which may cater us from the grass root level. Each religion has its own constitution which clearly manifests its functionality, rights and last but not the least limitations and position toward followers, simultaneously this particular approach also helps to formulate the internal structure of the religious groups within themselves. In this context we will also go through how religious ideology circulates and also is incorporated in the different nation building institutions in People's Republic of China.

'Religion' (Zongjiao), 'Xiejiao' (evil cult), 'Mixin' (superstition), 'MinjianXinyang' (popular faith), 'Wen hua' (culture), 'Wenwu' (cultural relic) - these all are just a concept which hits religion directly; henceforth, these classifications are the part of distinctive discursive network, involving a different type of dynamic relationship with the state along with its definitions of orthodoxy and produce a different kind of logic for the religious affiliation and action. Members of the discursive network that come from the different walks of life are expected to speak within the framework of Party policy. Thus party policy keeps on trying to build up a common discursive framework, which is inculcated and re-interpreted by actors with variety of interests and fidelities. The basic commitments of the religious affairs officials are to the government within the official framework as to strengthen the exact form and essence of 'Religion'. Different school of thoughts evolves through speech of party leaders; support the overreaching ground level work for the discursive network on religion. This analysis can be taken into an account of other voices from the same network and can act on the general theory of evolution of the international and domestic political context.

\section{Character}

The place of religion in Chinese society has become a subject of controversy and turn out to be opposing elements in the circumstance. Viewing Chinese religious life on the grass root level, gives an image of a normal man's mental status of the universe; truth be told, the entire example of life was intensely hued by the shadowy world of divine, spirits and specters. Chinese history very clearly discusses, there was no certain organized religious control in the early stage however Confucian morals ruled the domination of social values, qualities, to a great extent supplanting the ethical function of religion as found in Christianity.

Gradually, with the ideological evolution, scholars of modern China have developed the theme of the 'Religion' in Chinese society to a much greater extent. 
In the last 20 years in China religion and religious tradition have revived their activities and taken interdisciplinary action towards the revival of social freedom that has accompanied the economic development and diversified development of that period. The government focus on maintaining political control and legal restrictions remains, but whenever local situations permit, religious activities come on bubbling to the surface. The relation between religion and state power in China has been long contested. Dynastic relations with religious organizations and their own doctrine always attempt to capture the legitimacy through sponsorship of ritual; while folk religion continued to thrive in local society despite ongoing attempts at official control ${ }^{5}$.

\section{Basic Framework}

The notion of acceptance on religion is in close agreement with the Chinese notion of religion. In traditional Chinese language several agreements have been accepted and acclimated in religion; the word 'jiao' (guiding doctrine) is the closest agnate to the western appellation "religion". Thus the 'Fojiao' or the adoration of Buddha and there is 'BaiJiao' (the adoration of the white Sun). Another term in Chinese with the connotation of religion is Dao, which talks about the way, the abundant cosmological principle that governs the operation of the Universe including the human world; used in connection with religion belief and organizations in accumulation which directly indicates towards religious sect. During Mao regime China's socialist transformation programme challenged the social bases for traditional Chinese folk religion, while policies of political monopoly attached those limited examples of organized religion that could be identified and targeted ${ }^{6 *}$. Post Mao regime has adopted more tolerant approach on religion as a component of new vistas towards strong faith / belief on religion. While the early 80-s flagged an important phase of liberalization in comparison to previous period, fundamentally the party remained concerned on execution of social control, under the rubric of the dictatorship of the proletariat and the central role of the party leadership in the process of socialist modernization? ${ }^{7}$. It's just few years Mao died, memories of deep scars are still visible in people's mind; religious institution started taking shape, when the policy of religious freedom was resumed at the $11^{\text {th }}$ party Congress, and the state provided the mandate of "strengthening management" of religion and of actively guiding the adaptation of religion to socialism while emphasizing that "feudal superstition" remained forbidden". As the appointment of religious leaders have been held for the political purpose in 1950s and given the tasks of supervising the re-establishment and operations of the official religious associations, the registration and the management of clergy manage the place with a proper registration of place of religious worship.

\footnotetext{
${ }^{5}$ Arthur P., Wolf (Ed.) 1978, School-temple and city God, Studies in Chinese Society, A contemporary Sociology of worlds Religions, pp. 103-130, New York, NY New York University Press.

${ }^{6}$ Rennselaer W. Lee, 1964, General aspect of Chinese Communist Religion, China Quarterly, No. 19, pp. 161-173.

${ }^{7}$ Preamble to the 1982 Constitution of the PRC, 1986, Beijing, China, Beijing Law Publishers.

${ }^{8}$ Fully Implement the Policy of Religious freedom, in Maclnnis D., 2009, Religion in China Today, Issue 4, pp. 26-32.
} 


\section{System of religious management, non religious orthodoxies and heterodoxies}

In the 80-s officially the religious associations came into full play like, the China Muslim association, the Protestant-Catholic Association and therefore the China Buddhist Association and these associations were expected to consider their own system side and to continue their handlings with political relations with the government and CCP. A foremost concern of the religious associations is to concentrate on their issues associated with ordination, registration and management. Apart from that dealing with religious leaders as individuals, associations as corporate entities goes to the religious association. In practice, at lower levels of government, it is often the same official who is in charge of the United front, it is just another branch of CCP and this branch deals with 'new religion' established in 2005. After 1982 local religious academies were divided into small study groups, where, six Buddhist, five protestant and five Islamic schools appeared.

However this model might not be concentrated on framework, while the lower level religious affairs and united front officials are supposed to follow the directives and policies of the government they are delegated by the common and nearby government and gathering board of trustees, in which they stay responsible and not to the focal religious. The same situation prevails in the official religious associations, which were established at the provincial and zonal level throughout the $80^{\mathrm{s}}$ $90^{\text {s. The }} \mathrm{CBA}^{9}, \mathrm{CIA}^{10}$ organizations like these also start running smoothly since the 80 -s, while the patriotic association continued to handle political relations with the government and CCP. Although the concept of "Patriotic Education" was conceived earlier, but it was executed in all religious communities from 1994, the crux of the matter was integrating traditional forms of training and ordination with modern standardized process being furthered by the state as well as the question of political loyalty. The bureaucratic leaders are in sharp contrast to charismatic types outside of or on the margins of official institutions, were even though a fewer charismatic Buddhist and Daoist do get appointments in their associations ${ }^{11}$.

Temples remain core of the major tourist attraction and the highest level of revenue, leading to conflicts among religious associations and government agencies all claiming a share of the pie. The tourist and business potential of Buddhist sites has led towards a trend of local authorities and entrepreneurs to building on air gigantic Buddhas in order to catch more tourists and pilgrims; as a phenomenon which has been asserted by religious affairs officials.

The religion framework for the institution has very narrow interpretation of 'Religion', which does not include Cultural China much. Simultaneously, the restriction of 'Religion' leads to rush on the part of other actors, within and out of state both ways to execute the wide range of practices under non-religious banner, thus it tries to make legitimate practices-creating whatever Fenggang Yang has termed "Grey Market" of religion ${ }^{12}$. The gradual flourish of the relationship with the outside world has also led to arealisation, where, the dimension of religious exchange seeks to come out with a terminology of 'religious diversity' with China's

\footnotetext{
${ }^{9}$ China Buddhist Association, Issue 4, pp. 40-58.

${ }^{10}$ China Islamic Association, Issue 4, pp. 40-48.

${ }^{11}$ Yoshiko Ashiwa, David L. Wank, 2001, Pathways to the Pulpit: On the training of Protestant clergy, Leadership Training in Patriotic and Unregistered Chinese Protestant Churches, pp. 96-125, Vol. 40, London, UK, Stanford University Press.

${ }^{12}$ Fenggang Yang, 2005, The Red, Black, and Grey Markets of Religion in China, No 6, pp. $110-114$.
} 
international partnership. In 2005, a new series of policy regarding religion (Zongjiao shiwu tiaoli) has been implemented, which was basically the consolidated regulation of previous policies ${ }^{13}$.

\section{Conclusion}

The official discourses on China and its religion is now clearly pronounced as positive about religion and gradually become friendly within the religious community in China and all around the world. To be very practical, this is a true representation of gargantuan openness of 'Religion' towards general and also to a massive plurality of terms of religious expression of People's Republic of China. In one point this opening remains demure and its outcome remains to be observed; such an "opening" should not be fathomed out as leading to an inexorable Western (American) style of deregulation of the religious arena. Since 1979, religious policy of China has uninterruptedly looking for 'institutionalized religion' under CCP guideline, although in today's leadership does not allow religion-state to step out from its own domain, but it promotes 'Religion' as an official - religious institutions. These all neither advocate for their freedom, nor act of freedom rather it advocates for their better management for the process of effective institutionalization of social and cultural life of the people in mainland.

\section{REFERENCES}

Feuchtwang S. (1978), "School-temple and city God", in Wolf, A. P. (Ed.), Studies in Chinese Society, Stanford University Press, Redwood City, CA, pp. 103130.

Black B. and Patton L. (2015), Dialogue in early South Asian Religions, Routledge, London.

Fenggang Yang, (2005-6), "The Red, Black, and Gray Markets of Religion in China", The Sociological Quaterly, Vol. 47, No. 1, pp. 93-122.

"Fully Implement the Policy of Religious freedom", in MacInnis, D. (1989), Religion in China Today, pp. 26-32.

Ji Zhe (2008), "Secularization as Religious Restructuring: Statist Institutionalization of Chinese Buddhism and its Paradoxes", in Mayfair Yang (Ed.), Chinese Religiosities, Berkeley, C. A. University of California Press, California, pp. 233-261.

Marine Carrin, Pralay Kanungo (2014), The Politics of Ethnicity in India, Nepal and China, Primus Books, New Delhi.

Preamble to the 1982 Constitution of the PRC (1986), Beijing Law Publishers, Beijing, China.

Rensselaer W. Lee (1964), "General aspects of Chinese Communist Religious Policy”, China Quarterly, No. 19, pp. 161-173.

Leung B. (1995), "Religious freedom and the Constitution in the People's Republic of China: Interpretation and Implementation", Diskus, Vol. 3, No. 1, pp. 1-18.

Yoshiko Ashiwa and David L. Wank (Eds.) (2009), Making Religion, Making the state in China. The politics of Religion in Modern China, C. A. Stanford University Press, California.

Ying Fuk-Tsang (2005), "New Wine in Old Wineskins", in Feng and Li Jian (Eds.), Zongjiao shiwu tiaoli shiyi, Beijing University Press, Beijing.

\footnotetext{
${ }^{13}$ Ying Fuk-sang, Feng and Li Jian (Ed.), 2005, New Wine in Old Wineskins, Zongjiao shiwu tiaoli shiyi, Beijing, China Beijing University Press.
} 


\section{ФОРМУВАННЯ РЕЛІГІЇ В КИТАЙСЬКІЙ НАРОДНІЙ РЕСПУБЛІЦІ ІНТЕРПРЕТАЦІЯ ТА ІМПЛЕМЕНТАЦІЯ}

\section{Сувро Паруі}

Стаття висвітлює постійні зміни у процесі інституціоналізації, здійснюваному державою в Китаї, та їхній вплив на формування релігійного поля Китаю; нормативний дискурс про релігію та релігійні практики під світськими вивісками. Головний фокус дослідження, структурна точка зору була поєднана з функціональною точкою зору у визначенні релігії як системи віри, ритуальних практик і організаційних взаємин, створених для взаємодії з основними питаннями людського життя і відстоювання догматів в умовах суперечливих доказів реалістичного досвіду.

Ключові слова: дискурсивна мережа, характер, базова структура, система релігійного управління, нерелігійна ортодоксальність і неортодоксальність

\section{ФОРМИРОВАНИЕ РЕЛИГИИ В КИТАЙСКОЙ НАРОДНОЙ РЕСПУБЛИКЕ: ИНТЕРПРЕТАЦИЯ И ИМПЛЕМЕНТАЦИЯ}

\section{Сувро Паруи}

В данной статье рассматриваются постоянные изменения в процессе институционализации под руководством государства в Китае и их влияние на формирование религиозного поля Китая; нормативный дискурс о религии и религиозных практиках под светскими вывесками. Главный фокус исследования, структурная точка зрения была соединена с функциональной точкой зрения в определении религии как системы веры, ритуальных практик и организационных отношений, созданных для взаимодействия с основными вопросами человеческой жизни и отстаивания догматов в условиях доказательств реалистического опыта.

Ключевые слова: дискурсивная сеть, характер, базовая структура, система религиозного управления, нерелигиозная ортодоксальность и неортодоксальность

Стаття надійшла до редакиії 20.05.2019 